\title{
Proximate Composition of Fortified Filipino Snacks for Picky Eaters
}

\author{
Jhoanna B. Calubaquib, PhD. ${ }^{1, *}$ and Milagros C. Suyu, PhD. ${ }^{2}$ \\ 'Department of Science Education, College of Teacher Education \& Graduate School, \\ Cagayan State University-Andrews Campus, Caritan, Tuguegarao City, Cagayan, 3500, \\ Philippines \\ 2Department of Nutrition, College of Hospitality Management, Cagayan State \\ University-Andrews Campus, Caritan, Tuguegarao City, Cagayan, 3500, Philippines.
}

Article Type: Research Article

Article Citation: Jhoanna B.

Calubaquib. Proximate composition of fortified Filipino snacks for picky eaters. Indian Journal of Science and Technology. 2020; 13 (01), 61-69. D0l: 10.17485/ijst/2020/v013i01/ 149050

Received date: November 20, 2019

Accepted date: December 5, 2019

*Author for correspondence:

Jhoanna B. Calubaquib

jb_120771@csu.edu.ph P College of Teacher Education \& Graduate School, Cagayan State University-Andrews Campus, Caritan, Tuguegarao City, Cagayan, 3500, Philippines

\section{Abstract}

Objectives: The study aimed to determine the nutritive values of fortified Filipino snacks and to calculate the calorie value of the energy-yielding nutrients. Methods/statistical analysis: The Official Method of Analysis of Association of Official Analytical Chemists was used to analyze the proximate composition. The calorie content was calculated by the use of specific energy factors of 4:9:4 for proteins, fat, and carbohydrates, respectively. The majority of the food samples showed significant $(P<0.05)$ variations among the means concerning proximate composition. Findings: The highest protein was found in Moringa Sweet Potato Tuile, it can replace animalbased street foods. The moisture content of Saba-Potato Halaya was the highest and found lowest in Moringa Polvoron. The dry nature of Moringa Polvoron can prolong its shelf-life. It can substitute candies and gummies. The ash content was found highest in Moringa-Sweet Potato Tuile (MST). This can be associated with the mineral-dense Moringa and sweet potato. MST can be a healthier alternative for commercial pastries. The crude fiber content was again observed rich in MST. The Moringa and sweet potato are good fiber sources. MST is a healthier option than any fiber-rich junk food. Crude fat content was highest in Banana Blossom Bar. This snack can better substitute chocolate-flavored bars. The Jute-Spinach PastiYema was found richest with carbohydrates. It can be a healthier alternative for chocolate or marshmallow. All fortified snack samples are healthy calorie-containing foods suitable for picky-eating children. Application/improvements: If sufficiently consumed, these healthy snacks may contribute to the nutritional requirement of picky-eating children. This knowledge can be used to produce greener foods for school canteens in the Northern Philippines.

Keywords: Calorie Content, Fortified Filipino Snacks, Picky Eaters, Proximate Analysis, Proximate Composition 


\section{Introduction}

One beneficial strategy in ensuring and improving dietary intake other than with nutritional supplements is to increase nutrients and energy through dietary fortification [1]. Food fortification as the addition of one or more essential nutrients to food whether or not it is normally contained in the food to prevent or correct a demonstrated deficiency of one or more nutrients in the population or specific population groups. One of the several types of fortification programs around the world is the Targeted Fortification. This is performed when a particular group within a population, like the elementary or middle school learners, has a distinct risk for a nutrient deficiency which is maybe due to picky eating syndrome [2]. The addition of nutrient-rich vegetables to common snacks is one of the practices of Targeted Fortification.

Picky eating habit is usually associated with low fruit and vegetable intake [3]. The high amount of fatty and carbohydrate-rich foods in their diet may make them at risk of malnutrition [4]. The picky eating syndrome may also affect the child's personality, behavior, well-being and the relationship between the parent and the child [5]. The 8th National Nutrition Survey presented that for children 5-10 years old, 29.1\% were underweight, $29.9 \%$ were stunted, $8.6 \%$ were wasted, and $9.1 \%$ were overweight. The cause of malnutrition of some school children in the Philippines is due to inadequate total food intake. It is still commonly observed that children particularly in Northern Cagayan, Philippines prefer fast foods and junk foods [6].

Parents should be encouraged to include more nutrient-rich foods in the diet of their children especially fruits and vegetables [7]. Parents who role model the fruit consumption at snack would more likely to have children who could meet the recommended daily fruit and vegetable consumption [8]. It is for these reasons that at home, the parents try various practical means to combat the feeding disorder such as change of family meal style; make fun with veggie food art and garnish; engage children to meal planning; prepare colorful vegetable recipes, and some may even resort to making a meal for fun. However, these strategies oftentimes fail and may even resort to clinical treatment to ensure that children have healthy and safe food consumption. Furthermore, there were identified impediments to the intake of plant-based foods such as accessibility of fresh fruits and vegetables, the number of calories from fresh against processed foods, and availability of time and cooking knowledge and skills needed to prepare plant-based foods [9].

School-based health and nutrition initiatives may be improved by emphasizing on policies and interventions to address the unhealthy eating habits of the learners. Healthy diet defines as a balance in food consumption which obtains energy balance and normal weight; restricts energy intake from total fats and alters saturated fat consumption to unsaturated fats and toward the elimination of trans-fatty acids; increases fruits and vegetables intake, legumes, whole grains, and nuts; limits the free sugars in the diet; and limits salty foods [10]. The DepEd ensures that every school develops its healthy menu, with food and drinks that are nutritious and affordable. The DepEd order reads that the school canteen and DepEd offices shall not sell foods and beverages high in fat and/or sugar and/or table salt. The order also presented the importance of reading the Nutrition Facts of the products. 
The fortification advocacy program and food analysis must also be in place particularly at home and school. In the University, the promotion of healthy snack options in the community may be done in a multi-modal scheme that may be integrated for classroom instruction, research-based programs, information drive, and socio-environmental influences. The knowledge and skill in healthy food processing may be emphasized to come up with vegetable- and fruit-enriched snacks. The nutritionists and dieticians in the University carried out targeted fortification by blending the standard food components of common Filipino snacks such as Polvoron (shortbread), Tuile (baked wafer), Cookie Bar, Halaya (Jam), Pasti Yema (candy) and Pastillas (candy) with nutrient-dense plant materials that are readily available in Northern Cagayan, Philippines. These plant materials used for the samples were Malunggay leaves (Moringa oleifera), Spinach leaves (Spinacia oleracea), Jute leaves (Corchorus olitorius), Sweet Potato tuber (Ipomoea batatas), Potato (Solanum tuberosum), Cacao (Theobroma cacao) and Rice grains (Oryza sativa). Furthermore, scientific food evaluation processes are introduced to address the problems of nutrient deficiencies and feeding difficulties of the target population. These processes are food preservation techniques; phytochemical screening, proximate analysis and identification of bioactive components of plant materials; organoleptic evaluation and microbial analysis of food products. However, proximate analysis to determine the nutritive values of the fortified Filipino snacks has not yet carried out. The findings of the study are used as baseline data for the sustainable health and nutrition extension program of the University. The results obtained are also used as initial data for the labeling of processed fortified snacks to comply with the mandatory labeling requirements of the Bureau of Food and Drug Administration in the Philippines. This is to ensure the food safety of the products when exhibited by the University during regional and national Science Trade Fairs. Moreover, the nutrition information is an added face-lift to increase product marketability and business integrity.

The study aimed to determine the proximate composition of the fortified Filipino snacks for picky eaters. Specifically, it sought to determine the nutritive values of the selected fortified Filipino snacks such as Moringa Polvoron (MP), Jute-Spinach Pastillas (JSP), Saba-Potato Halaya (SPH), Moringa-Sweet Potato Tuile (MST); Rice Krispie- Sweet Potato Pasti Yema (RSP), and Banana Blossom Bar (BBB) in terms of their moisture, ash, crude protein, crude fat, crude fiber and carbohydrate contents. The study also estimated the total calorie content from fats, proteins, and carbohydrates obtained from the snacks. The nutritional data obtained through proximate analyses of fortified Filipino snack samples are still uninvestigated, hence, the study was conducted.

\section{Materials and Methods}

\subsection{Collection of Food Samples}

The fresh green leafy vegetables, tubers, rice grain, and cacao beans were collected from insecticide- and fertilizer-free farm from Sta. Maria, Lal-lo, Cagayan, Philippines. The fortified Filipino snack samples were prepared at the College of Hospitality Management Food Laboratory, Cagayan State University- Andrews Campus, Tuguegarao City, Cagayan, 
Philippines. These snack samples include Moringa Polvoron, Jute-Spinach Pastillas, SabaPotato Halaya, Moringa-Sweet Potato Tuile; Rice Krispie-Sweet Potato Pasti Yema, and Banana Blossom Bar. They were kept separately in sterile labeled containers. The prepared samples were then transported immediately to the DOST Regional Standards and Testing Laboratory-Region 02, Tuguegarao City, Cagayan, Philippines 3500 for the analysis of their proximate composition.

\subsection{Proximate Analysis}

One hundred grams of each of the fortified Filipino snack samples were analyzed for proximate composition in terms of moisture, protein, fat, ash, and carbohydrate by the standard methods published by the Association of Official Analytical Chemists. Moisture content was computed by the Gravimetric method of weight loss after drying the samples in an oven at $105^{\circ} \mathrm{C}$ until a constant weight was achieved. Protein was determined by the Kjeldahl method, and thenceforth a conversion factor of 6.25 was used to calculate the total nitrogen to crude protein. The ash content was estimated by Gravimetric measurement of the samples in the furnace at $550^{\circ} \mathrm{C}$ until the constant weight was obtained. Crude fat was analyzed by the Soxhlet extraction method. The digestible carbohydrates were calculated by difference, i.e. $100 \%$ moisture $+\%$ protein $+\%$ fat $+\%$ ash $+\%$ crude fiber [11].

\subsection{Calorie Content}

The calorie content (Kcal/100 g) of the snack samples was calculated by the use of specific energy factors of 4:9:4 for proteins, fat, and carbohydrates, respectively.

\subsection{Statistical Analysis}

All six fortified snack samples were analyzed in triplicate. The data obtained through a proximate analysis were analyzed using SPSS version12. Differences between means were evaluated by the standard deviation. Statistical significance at the $95 \%$ probability levels was set at $p<0.05$.

\section{Results and Discussion}

The concentrations of protein, moisture, ash, fiber, fat, and carbohydrate of fortified Filipino snacks are presented in Table 1.

\subsection{Proximate Composition}

\subsubsection{Crude Protein}

The crude protein contents in MP, JSP, SPH, MST, RCP, BBB were found to contain $7.51 \%, 2.41 \%, 1.00 \%, 11.63 \%, 4.96 \%$, and 9.84\%, respectively. MST has the highest protein value. This can be associated with the Moringa leaves and the cacao bean powder 
TABLE 1. Proximate composition of fortified Filipino snacks (Mean $\pm S D, n=3$ )

\begin{tabular}{lccccrr}
\hline \multirow{2}{*}{ Nutrients } & \multicolumn{7}{c}{ Proximate Analysis $(\mathbf{g} / \mathbf{1 0 0 g})$ Mean \pm SD } \\
\cline { 2 - 7 } & \multicolumn{1}{c}{ MP } & \multicolumn{1}{c}{ JSP } & \multicolumn{1}{c}{ SPH } & MST & \multicolumn{1}{c}{ RSP } & BBB \\
\hline Protein & $7.51 \pm 21.81$ & $2.41 \pm 0.19$ & $1.00 \pm 0.07$ & $11.63 \pm 0.16$ & $4.96 \pm 0.06$ & $9.84 \pm 0.16$ \\
Moisture & $5.34 \pm 0.11$ & $6.24 \pm 0.89$ & $34 \pm 0.40$ & $7.39 \pm 0.070$ & $18.52 \pm 1.09$ & $14.34 \pm 0.37$ \\
Ash & $1.18 \pm 0.02^{\text {ns }}$ & $2.39 \pm 0.06$ & $0.79 \pm 0.04^{\text {ns }}$ & $3.37 \pm 0.17$ & $1.63 \pm 0.03^{\text {ns }}$ & $1.91 \pm 0.13$ \\
Fiber & $11.27 \pm 0.88$ & $2.16 \pm 0.22$ & $2.3 \pm 0.30$ & $12.23 \pm 0.55$ & $2.16 \pm 0.40$ & $4.966 \pm 0.31$ \\
Fats & $26.82 \pm 1.80$ & $7.14 \pm 0.31$ & $0.24 \pm 0.17$ & $20.61 \pm 0.81$ & $19.65 \pm 0.27$ & $28.32 \pm 0.92$ \\
Carbohydrate & $59.14 \pm 5.81$ & $81.83 \pm 0.72$ & $63.97 \pm 0.23$ & $57.01 \pm 1.14$ & $55.24 \pm 1.25$ & $45.59 \pm 0.77$ \\
\hline
\end{tabular}

Legend:

MP- Moringa Polvoron

JSP-Jute Spinach Pasti Yema

SPH- Saba Potato Halaya

MST- Moringa Sweet Potato Tuile

RSP- Rice Krispie Sweet Potato Pasti Yema

BBB- Banana Blossom Bar

SD-Standard Deviation

ns-not significant

in MST, both rich in protein. Eating Moringa food products is good for those suffering from malnutrition for $100 \mathrm{~g}$ of its leaves contains $8.1 \mathrm{~g}$ [12]. The protein concentrations of roasted cocoa beans varied from different countries of origin (Dominican Republic, Ivory Coast, Ecuador, Madagascar, and Echeandia), ranging from $6.39 \mathrm{~g}$ to $17.26 \mathrm{~g}$ per $100 \mathrm{~g}$ [13]. The protein content of the BBB ranked second with $9.84 \%$. This result is in close agreement with the previous research finding that $100 \mathrm{~g}$ of banana blossom contains $1.62 \%-2.07 \%$ of protein [14]. The least protein is given to $\mathrm{SPH}$, this can due to its main ingredient, the carbohydrate-rich potato, and saba. However, plant-based proteins used in all these snacks can be a good replacement for animal-based and protein-rich snacks.

\subsubsection{Moisture}

Moisture content in the fortified products ranged from $5.34 \%$ in MP to $34.0 \%$ in SPH. The moisture content of SPH was the highest among all other snack samples, possibly because its preparation required a considerable volume of water; and can be attributed to the natural liquid content of Saba and Potato. In terms of product stability, increased moisture content tends to hasten microbial contamination and chemical degradation, as it provides a medium for many reactions to occur [15]. The minimal amount of moisture content in MST, JSP, and MP can prolong their shelf-lives, this implies that these relatively dried snacks have good storage quality and can be disposed of by school canteens over a long period. Moreover, these snacks are better options for any type of sugary candies, gummies, and chocolates.

\subsubsection{Ash}

All the six fortified snacks contained ash content ranging from $0.79 \%$ to $3.3 \%$. MST obtained the highest ash content with $3.37 \%$ with Moringa as its bulk content. This indicated the presence of minerals, hence, this particular result is in agreement with the 
previous research findings, that mineral Potassium in Moringa is 15 times more than bananas and 25 times more Iron than spinach [16]. MST can be a healthier alternative for sugary cupcakes and cookies. MP with $1.18 \%$ of ash may also be associated with the added Moringa powder to its high protein flour. The JSP got the second richest ash content $(2.39 \%)$ since it contained Jute and Spinach leaves which both bear a considerable amount of Calcium and Iron [17]. It is also important to note that the ash contents of the tuber-containing snacks such as SPH and RSP are maybe attributed to the common minerals contained in potatoes and sweet potatoes like Calcium, Magnesium, Potassium, Phosphorus, and Sodium. Tubers and roots are a potential functional food, they provide several desirable nutritional and health benefits to ensure general wellness [18]. Saba fruit also contains calcium, phosphorus, and iron [19]. High-protein flour is used as a standard ingredient of the fortified tuile, cookie bar, and polvoron samples. High protein flour is associated with high ash count especially from wheat grown in mineral-rich soil [20].

\subsubsection{Fat}

Fat content in all the snack samples reflected the highest mean score as compared to the other nutrients, this is maybe due to the main ingredients common in all the snack samples such the fatty dairy products- butter and milk. The BBB contained the highest fat content with $28.32 \%$. This finding could be attributed to the added fat-rich chocolate chips and egg. However, this snack can better substitute chocolate-flavored bread, cookies, and cupcakes with artificial additives. The snack with the lowest fat content was the SPH. As regards to food stability, relatively high-fat content could be undesirable in baked food products like the BBB because it can promote rancidity in foods [21].

It is important to note that diet providing $1-2 \%$ of its caloric energy as fat is said to be sufficient because of too much fat in the diet of kids and carry excess weight into adulthood have a greater risk of heart disease, high blood pressure, and diabetes [22]. With this current study, it is suggested that healthy fats with plant-based fortified snacks may be taken in proper amounts since they supply energy suitable for the active lifestyle of school children and teenagers. Most of the fortified snack samples contain healthy monounsaturated fats from soya oil.

\subsubsection{Carbohydrate}

The carbohydrate content was relatively high with values ranging from $45.59 \%$ BBB to $81.83 \%$ JSP. The highest percentage of carbohydrates was recorded for JSP with $81.83 \%$, while the lowest was observed for $45.59 \%$ in BBB. JSP can be a healthier alternative for chocolates, lollipop or marshmallow. The whole wheat from the flour, the brown rice for rice-crispies, tubers, and non-starchy vegetables like Moringa, spinach, and jute contained in the snack samples are good sources of complex carbohydrates. These food materials can provide long-lasting energy necessary for the active brains and moving muscles of the children. The unfortified forms of these snacks with high sugar, starch, and fat components may contribute to hyperactivity, mood disorders, and increase the risk of obesity, and type 2 diabetes [23]. 


\subsubsection{Fiber}

The snack samples were analyzed to contain crude fiber from $2.16 \%$ to $12.23 \%$. This means that 10-20 g per serving of these snack samples is sufficient to provide the $14-31 \mathrm{~g}$ fiber requirement of children between ages 1 to 18 . The crude fiber content was found highest in MST. Higher fiber intakes, seen in countries around the world, may significantly reduce chronic disease risk [24]. MST is a healthier option than any fiber-rich junk foods like the salty cereal and grain chips, and cheesy potato fries.

\subsection{Caloric Content}

The calorie contents of the fortified Filipino snacks are indicated in Table 2. The results show that MP has the highest calorie with 507.98, followed by BBB with 476.61. The SPH obtained the lowest calorie value. It is reflected that all the calorie values fairly exceeded the recommended caloric snack intake per day. Nutrition experts estimate that the snack consumption of the children should not exceed 200 calories, however, each has a distinct caloric requirement based on personal health goals and/or nutritional or medical needs. However, all these fortified snacks are healthy calorie-containing foods suitable for pickyeating children.

TABLE 2. Caloric content of fortified food snacks using the available nutrient parameters (Kcal/100 g)

\begin{tabular}{lcccccc}
\hline Calorie & MP & JSP & SPH & MST & RSP & BBB \\
\hline Kcal/100 g & 507.98 & 401.22 & 262.04 & 460.05 & 417.65 & 476.61 \\
\hline
\end{tabular}

\section{Conclusion}

These fortified Filipino snacks which contain an appreciable amount of nutrients can be a good food supplement for picky eaters needed to maintain a healthier diet. The snack samples can be kid-friendly junk food alternatives. The minimal amount of moisture content observed in all the snack samples may prolong their shelf-lives. The ash content is also an important component in health and nutrition, quality and, like moisture, microbial viability. It is suggested that picky eaters, active learners, athletes and those who intentionally skip meals may consume such healthy snacks with reasonably high calories. However, in the absence of any of these conditions, consuming these high-calorie snacks may only add extra calories in the diet resulting in the accumulation of body fat. Whether fussy eaters or not, children do not always eat what is healthy for them. Hence, it is suggested that starchy, sugary and fatty Filipino snacks should be made healthier and more enticing with the locally available fruits and vegetables through fortification. The results obtained in this study are used as a sustainable health and nutrition extension program of the University and indispensable to comply with the mandatory labeling requirements for the fortified snacks produced by the Cagayan State University-Andrews Campus. 


\section{Acknowledgment}

The authors wish to thank the Cagayan State University-Andrews, Caritan, Tuguegarao City, Cagayan, the Philippines for the financial assistance and the use of physical resources of the University. The authors also thank the management and the laboratory staff of the Department of Science and Technology Laboratory Testing Region 02, Tuguegarao City, Cagayan, the Philippines for the technical assistance and the use of facilities.

\section{References}

1. Troesch B, Biesalski HK, Bos R, Buskens E, Calder PC, Saris WH, Eggersdorfer M. Increased intake of foods with high nutrient density can help to break the intergenerational cycle of malnutrition and obesity. Nutrients. 2015; 7(7), 6016-6037.

2. Dary O, Hurrell R. Guidelines on food fortification with micronutrients. World Health Organization, Food and Agricultural Organization of the United Nations: Geneva, Switzerland. 2006, 1-376.

3. Steinsbekk S, Bonneville-Roussy A, Fildes A, Llewellyn CH, Wichstrøm L. Child and parent predictors of picky eating from preschool to school age. The International Journal of Behavioral Nutrition and Physical Activity. 2017; 14(1), 87.

4. Fisher JO, Birch LL. Fat preferences and fat consumption of 3-to 5-year-old children are related to parental adiposity. Journal of the American Dietetic Association. 1995; 95(7), 759-764.

5. Draxten M, Fulkerson JA, Friend S, Flattum CF, Schow R. Parental role modeling of fruits and vegetables at meals and snacks is associated with children's adequate consumption. Appetite. $2014 ; 78,1-7$.

6. $8^{\text {th }}$ National nutrition survey in the Philippines. https://www.fnri.dost.gov.ph/images/sources/ anthrop_children.pdf. Date accessed: 2013.

7. Taylor CM, Northstone K, Wernimont SM, Emmett PM. Macro-and micronutrient intakes in picky eaters: a cause for concern? The American Journal of Clinical Nutrition. 2016; 104(6), 1647-1656.

8. Trofholz AC, Tate AD, Draxten ML, Rowley SS, Schulte AK, Neumark-Sztainer D, Berge JM. What's being served for dinner? An exploratory investigation of the associations between the healthfulness of family meals and child dietary intake. Journal of the Academy of Nutrition and Dietetics. 2017; 117(1), 102-109.

9. Beaulac J, Kristjansson E, Cummins S. Peer-reviewed: a systematic review of food deserts, 1966-2007. Preventing Chronic Disease. 2009; 6 (3), 105.

10. Official methods of analysis of AOAC international - 20th edition. https://www.techstreet.com/ standards/official-methods-of-analysis-of-aoac-international-20th-edition-2016?product_ id=1937367. Date accessed: 2016.

11. Department of Education order No. 13, series 2017-policy and guidelines on healthy food and beverage choices in schools and DepEd offices. https://www.teacherph.com/guidelines-healthyfood/. Date accessed: 14/03/2017.

12. Abbas RK, Elsharbasy FS, Fadlelmula AA. Nutritional values of Moringa oleifera, total protein. amino acid, vitamins, minerals, carbohydrates, total fat and crude fiber, under the semi-arid conditions of Sudan. Journal of Microbial and Biochemical Technology. 2018; 10, 56-58.

13. Bertazzo A, Comai S, Brunato I, Zancato M, Costa CV. The content of protein and non-protein (free and protein-bound) tryptophan in Theobroma cacao beans. Food Chemistry. 2011; 124(1), 93-96. 
14. Sheng ZW, Ma WH, Jin ZQ, Bi Y, Sun ZG, Dou HT, Han LN. Investigation of dietary fiber, protein, vitamin $\mathrm{E}$ and other nutritional compounds of a banana flower of two cultivars grown in China. African Journal of Biotechnology. 2010; 9(25), 3888-3895.

15. Ooi DJ, Iqbal S, Ismail M. Proximate composition, nutritional attributes and mineral composition of Peperomia pellucida L. (Ketumpangan Air) grown in Malaysia. Molecules. 2012; 17(9), 11139-11145.

16. Gopalakrishnan L, Doriya K, Kumar DS. Moringa oleifera: a review of nutritive importance and its medicinal application. Food Science and Human Wellness. 2016; 5(2), 49-56.

17. Islam MM. Biochemistry, medicinal and food values of jute (Corchorus capsularis L. and C. olitorius L.) leaf: a review. International Journal of Enhanced Research in Science Technology \& Engineering. 2013; 2(11), 135-44.

18. Chandrasekara A. Roots and Tubers as Functional Foods. In: Bioactive Molecules in Food. Reference Series in Phytochemistry. Mérillon JM., Ramawat K. (eds.), Springer, Cham. 2018.

19. Boamponsem GA, Johnson FS, Mahunu GK, Awiniboya SF. Determination of the biochemical composition of Saba senegalensis (Saba fruit). 2013.

20. What is ash in food? https://www.livestrong.com/article/449416-what-is-ash-in-food/. Date accessed: 2019.

21. Ajani, Alice O, Oshundahunsi OF, Akinoso R, Arowora KA, Abiodun A, Pessu, PO. Proximate composition and sensory qualities of snacks produced from breadfruit flour. Global Journal of Science Frontier Research. 2012; 12(7), 1-8.

22. Kris-Etherton PM, Harris WS, Appel LJ. Fish consumption, fish oil, omega-3 fatty acids, and cardiovascular disease. Circulation. 2002; 106(21), 2747-2757.

23. Azadbakht L, Esmaillzadeh A. Dietary patterns and attention deficit hyperactivity disorder among Iranian children. Nutrition. 2012; 28(3), 242-249.

24. Recommended daily intake of fiber per day. American Heart Association. https://www. healthline.com/health/food-nutrition/how-much-fiber-per-day. Date accessed: 29/07/2017. 